\title{
The Role of Financial Globalization in the Propagation of the World Financial Crisis
}

Mikhail Zharikov

\author{
Doctor of Economics, \\ Professor at World Economy and World Finance Department, \\ Senior Scientific Fellow at Institute for World Economic and International Finance Studies, \\ Financial University, Moscow, Russia \\ michaelzharikoff@gmail.com \\ http://orcid.org/0000-0002-2162-5056
}

Abstract

This article is specifically devoted to financial globalisation and financial crises in the early $21^{\text {st }}$ century. Obviously, it is a topic everyone is interested in after the global financial crisis of 2008-2010, the worst global financial crisis since the Great Depression. Its effects are still felt across the world today. Both industrial and emerging countries still suffer from high unemployment. In some of them, GDP has not yet reached pre-crisis levels. And this global crisis - if it were not enough - was followed very quickly by the Eurozone's sovereign debt crisis, which even though Ireland and now just recently Portugal have returned to private borrowing markets, is not resolved at all and is pretty much in remission but could come back. Lately, there have been concerns about emerging markets, including the BRICS, starting in 2016. There are various tremors in the emerging markets, capital outflows and currency depreciation. So, all over the world, one can see events that potentially cause questions about financial stability, which is an especially acute issue to look at. Keywords: financial globalisation, world financial crisis, the BRICS, international monetary system. JEL Classification: F37

\section{Introduction}

This article is focused mainly on the four questions:

- What is the financial crisis?

- Why do they matter?

- Is the recent experience very unusual in a broad sweep of history?

- Is there a unique role for financial globalisation in the process?

Most of the discussion in the US around the global financial crisis did not heavily emphasise the universal aspects, but for those of economists who work in the field of international economics and international finance, those loomed very largely. This chapter brings those aspects into the discussion. And finally, do the countries of the world do anything to reduce financial crisis risk? Can the governments do anything to reduce financial crisis risk? And what are the key takeaways on that important set of policy questions?
First of all, what is a financial crisis? It is hard to define it unambiguously, in a way that will make everybody feel confident about its meaning, partly because they can originate in various parts of the financial system as the chapter proceeds to discuss. And they can also be a matter of degree.

What the policymakers mostly fear are what economists call systemic crises, really large-scale crises that call into question the stability of the entire system. For example, if someone has a student loan, and the student defaults on it, that is not a crisis. It may be a crisis for that student alone, but it is not the crisis for the economy. On the other hand, if $40 \%$ of students default on their loans, that starts to be a crisis because the lenders who have lent to them get into trouble, and therefore the lenders who have lent to them potentially might go bankrupt as well.

So, in general, a financial crisis is a situation, in which a significant fraction of private 
actors (who can be households, firms or banks, or even some public actors who can be local governments or the national government) fail to appeal financial commitments with disruptive effects on the general economy. Looking at the 2008-2009 global financial crisis, it broke out when households a little bit earlier had started defaulting on mortgages calling into question the solvency of the holders of these mortgages, who, as it turned out, were scattered worldwide, which is where the international aspect came in (Afontsev, 2009).

One fundamental point to make about big systemic crises is that they are associated with declines in aggregate output. And just for the past 22 years, economists list some of the broader crises that have occurred, and one can see pretty clearly that in various regions of the world there are effects of it. Sometimes one sees direct impacts; sometimes, one sees spill-overs. And one should mention for interpreting this; it is true for all advanced economies that are included in the zero-zone, which can be shown separately along with the emerging and developing countries. So, one of the essential crises preceding the global financial crisis of 2008-2010 was the European monetary system crisis of the early 1990s, which centred around the origins of the euro seven years later; the Asian crisis of 1997-1998 had a big effect on emerging markets, and the dot-com crash in the early 2000 s which was very clearly in evidence of high-tech companies ' crisis (Andronova, 2012).

The global crisis is enormous in its effects. It is self-evident, and then the euro crisis, which like many crises can be seen most clearly with its effects in the euro area, but arguably their spillovers to developing the world as well became greater over this period as countries became more highly linked not only by trade but importantly given financial markets.

In fact, the above events are all different sorts of crises with their very different effects. The recent crisis was marked by a lot of banking distress. And so, banking crises are one prominent form of crisis. Banks have short-term liabilities but tend to hold longer-term assets or more illiquid assets. They provide liquidity to depositors and other short-term creditors. But if all of those depositors or creditors demand repayments at once, the bank is going to have a lot of trouble meeting those obligations. When this happens on a large scale, banking crises arise.

Governments sometimes default on their debt obligations. Most recently one saw a very well publicised technical default by Greece in the Eurozone, but other countries default all the time, particularly in the developing and emerging world, and, of course, even in the US (Arner, Taylor, 2009).

There has been a lot of discussion in the economics of a default surrounding the extension of the US debt limit. So, default is an essential category of a crisis. And another one that is less familiar for people who only look domestically is the currency crisis. Countries sometimes fix exchange rates because they want the exchange rate not to be bouncing around for various reasons. And in this sort of situation, a government can come under pressure when markets doubt its commitment because by fixing the exchange rate the government is providing basically a one-way bet to markets who think that the exchange rate will move in the other direction (Beder, 2009).

In fact, these are the three main crisis categories that have been studied in international finance, but one can also think these significant areas of transmission mechanisms for other crises or amplification mechanisms, problems can arise with mortgages as in the recent US experience with sovereign debt, and then it may get propagated through other markets.

Going back, the EMS crisis was a currency crisis. The Asian crisis involved elements of currency, banking and sovereign-debt issues. The dot-com crash is impressive because it wiped out holders of overpriced equities. But because they were not highly levered, it did not propagate to banks in the United States. However, in some emerging markets, it was associated with a lot of corporate defaults which put some pressure on banks (Chen, Milesi-Ferretti, Tressel, 2012).

The global crisis was basically a banking crisis, not much in the way of a currency crisis, and the euro crisis has everything in it. It has a sovereign debt aspect. It has a banking aspect and even a currencies aspect in the sense that markets began to doubt whether the countries that were in the Eurozone would be able to stay within the Eurozone and might not have to exit and adopt new currencies. 


\section{Contagion Effects of the Global Financial Crisis}

There are two themes that this article is going to talk about to just put the crises in context how economists like to think about them. And the two crises, the two concepts of the crises are interconnection and expectations. So, when one wants to think about the vulnerability of an economy to a crisis, the first thing one wants to think about is how interconnected financial markets are because there can be essential domino effects. As in the example with student loans, if one student does not repay his/ her debts, anyone who is relying on their cash to come in so that they can repay their debts, may themselves be forced to default, triggering a whole cascade of defaults in the system. And this is the kind of systemic effect that central bankers and finance ministers fear (Chorev, Babb, 2009).

The problems are especially severe when there is a lot of complexity and a lot of interconnection among institutions. And one of the issues that economists have turned to study recently is networks or financial networks, which may help explain how interconnected financial institutions are, and how one can use those interconnections to measure vulnerability. It is likely to be a significant research area going forward.

But banking crises are not events that happen in a vacuum anymore, in a sense that governments feel a responsibility to step in and do something.

In 1907, the US had a significant crisis. The US had no central bank, and it was private institutions led by J.P. Morgan, who himself stepped in to stem the situation, so this led directly to the founding of the Fed.

But nowadays, the government is going to step in with all sorts of monetary and fiscal tools when a banking crisis arises. The problem is that the government's interventions can put the government itself into a precarious financial situation. And in the euro crisis, one saw this in several countries.

For example, Spanish banks got into trouble. The Spanish government incurred debts in supporting them. Suddenly, the Spanish government had a high debt-to-GDP ratio. Ireland's case was even more dramatic. Ireland entered the global crisis with a debt-to-GDP ratio of around $20 \%$.
They came out of recession at the time of the euro crisis with a debt-to-GDP ratio of 1 . And it is because they had been supporting banks by issuing government debt.

Of course, when all of these network effects were being realised, and as a systemic crisis, there was a lot of imperfect information. Nobody knows what is on the balance of the key actors, or who are exposed to their potential defaults. And so, the causes were what economists call contagion. Of course, doctors also use the concept of contagion, and that is very similar.

So, the second key issue is expectations. If we think about expectations evolving during crises, the most important question is about the ways policy can manage expectations. To some degree, there is clearly a psychological element in crises. People talk about panics. People talk about fear. Some economists have done research on these issues during crises. But if one takes a pure rational perspective, there is the possibility of multiple equilibria setting off crises (Dorrucci, McKay, 2011).

What is meant by multiple equilibria? Again, one should think of the case of a bank. The bank has

- illiquid assets;

- very liquid liabilities;

- usually, the bank relies on a steady inflow and outflow of deposits;

- so that it never has to pay off too many depositors at once,

- that works effectively;

- and the bank makes profits.

But suppose there is some bad news about the bank. It may not even be such terrible news, but markets get the idea, and the depositors get the idea that the bank is weak and that maybe it is insolvent, or possibly its assets cannot cover its liabilities. Then those depositors may or may not ask for a repayment. And if that happens all at once, the bank is going to fail.

Many mechanisms have been put in place to try to deal with this problem. The most effective has been deposit insurance, which was put in place in the US after the beginnings of the Great Depression when many banks failed. But banks increasingly rely on wholesale lenders, i.e. large lenders who are not protected under the umbrella of deposit insurance. Those people can also cause a run on a bank. 
And so, this is something that one saw in great abundance during the global financial crisis of 2008-2010. Sovereign debt can have similar dynamics if everyone in the marketplace decides that Italy, say, is insolvent, then they will charge it higher interest rates, and it may indeed become unable to pay its bills.

On the other hand, Italy, with a debt-to-GDP ratio of 100 per cent, and paying interest rates of 3 per cent on that debt, got a 3 or 4 per cent of GDP a year. That is a manageable fiscal problem, provided one can collect taxes, which is not easy in Italy and even harder in some other European countries (Elyanov, 2009).

But in principle, one can see how that GDP ratio may influence the markets. The markets will suddenly say they need 10 per cent debt service, because Italy may default. So, the country has a real problem.

\section{Crises Types}

There are many varieties of crises, and they interact, and that can make them even more systemic. The crises have been around for a long time. They did not start in 2007. They did not begin in 1992. There is one example. One of the earliest sovereign debt crises involved an actual sovereign, Edward III who had the idea of invading France to regain lands that he believed rightfully belonged to him, except they did not have the money to do this, because Britain was somewhat advanced in its sense that the sovereign could not just tax people in an unlimited way. They had had the Magna Carta, etc. So, Edward hit on the idea of borrowing from Italian bankers, the idea being that once he had regained all these rich lands in France, he would repay them. His invasion did not go well, and he ended up defaulting which bankrupted the Italian lenders and set off a credit crisis in the Mediterranean.

The US states defaulted on foreign debt earlier in the $19^{\text {th }}$ century. The big global crisis in 1890 , the Baring crisis began with loans to Argentina, mostly by England. The US panic of 1907, which was already mentioned, 1929 Crash, etc. The entire globe operated under the system of fixed exchange rates up until the early 1970 s, when they collapsed in a series of very dramatic speculative attacks (Griesgraber, 2009).

The 1980s were dominated by a debt crisis in developing countries, which led to a decade of lost growth in Latin America. And there were lots of near misses also. If you follow this stuff, longterm capital in 1998 was a near miss. And even the developing country debt crisis in the 1980s could have been a much larger crisis because many US banks had lent heavily to countries that were in danger of default. And had they defaulted, it could have wiped out the equity of these banks (Helleiner, 2009).

Here are some very rough numbers just to give an idea of magnitudes. A group of economists did a recent tabulation, going from 1973 to 2006 only, and they counted 127 currency crises, 62 banking crises and 74 default crises in 79 countries. The definitions of these are open to discussion, but the order of magnitudes is pretty accurate. And of course, after 2006 and only up until 2010, not including the Eurozone events, they saw further six external default episodes, nine currency crises and 21 banking crises. And those were mostly advanced countries.

In fact, it is very striking to look at the sort of the incidence frequency of on-going banking crises. Since 1970 - and some data were put together at the IMF - there were many advancedcountry banking crises. And what one sees very clearly here is that the global crisis was indeed a massive banking crisis in the advanced countries, and these countries figured out how to do with financial regulation. There are powerful institutions to do this. Emerging markets have poor governance, and that is why they have so many banking crises. And of course, there had been events in the advanced countries and the richer countries, but they were comparatively rare. But advanced-country banks are of going down in droves. The euro crisis is also included here by the way, but the euro crisis is pretty much driven by a lot of the same elements that drove the global financial crisis, so not surprising that it continues (Jordà, Schularick, Taylor, 2011).

If crises had been for a long time, and if now they have moved big time to the richer countries, it raises the question, how they changed in some way, so what some reasons are for this. And now, if one looks at precursors of crisis in their aftermaths, statistically, one of the striking things is that qualitatively at least they are very similar to advanced countries and emergingmarket countries. The causes and effects seem not to be very different. There can be quantita- 
tive differences, and each crisis is a specific event (Kemenyuk, 2009).

One can find some broader regularities, but they play out in their own ways. Often crises come as twins, i.e. banking and currency or banking and sovereign debt, or even as triplets - all three, and indeed that has been true in the euro area where the first act was a banking crisis. But two robust predictors were the rapid growth of credit in the economy and bank credit and a rise in what international economists call the real exchange rate, which is the competitiveness of one economy compared to other economies. And to give an idea of what a domestic credit data would look like for the euro crisis, they are domestic credit as a ratio of GDP. And, it is pretty dramatic, particularly in Portugal, Spain and Ireland. Though if one looks at Germany, domestic credit since the start of the euro which was January 1999 is pretty much flat, leading up to the crisis. Greece was down, and there was a significant increase in domestic credit. So, this idea that if there is a lot of lending going on, and if it is proliferating that one should worry, maybe banks are moving along the extensive margin of quality. It seems to be a compelling issue in the data (Kose, Prasad, Rogoff, Wie, 2009).

\section{Financial Globalisation Effects}

So, this brings the reader to financial globalisation and the role that it may play in crises. Financial globalisation at some level, is a twoedged sword. It is a form of trade between countries, and it is known from fundamental economics that there can be gains from trade. And similarly, there are significant theoretical benefits of globalised finance that are quite analogous to the gains from the international trade of textiles, wine and commodities. There are two main categories of financial trade:

- trade over time, when a country with needs capital beyond its income may borrow from countries that have needs that are less than their income and pay back later;

- also, there are countries trading across what economists call in a jargon uncertain states of nature.

Basically, one does not know what event is going to happen in the future, but companies want to hedge their risks against these events. For example, someone is going to sell a security that pays if they have a bad outcome, and one is going to sell security under which they pay if one has a bad outcome. One, straightforward way of thinking about the diversification is in terms of equity markets (Lane, Milesi-Ferretti, 2011).

For example, one country has a stock market; and a second country has a stock market. If both these countries swap shares so that now someone is holding half of the other's shares and half of their shares, and the others are doing the same, then they have diversified their risks, and they have managed to find an allocation that they both prefer because their risks are lower. So, this diversification, or insurance as a form of trade against states of nature.

One is going to pay the insurance company in the US where a house does not burn down, but when the house burns down, they will pay the holder. So, this is indeed important. But the shortcoming of this sort of trade is that one cannot be sure that when the time comes for contractual payments to be made, but they actually will be made.

In another example lends lent to Greece. They sell a bond. They are supposed to pay back. What happens if they default or someone made contact with a bank that that is going to cover foreign exchange risk by buying a currency that one will have on a future date, and selling a currency that one needs on the future date? What if that bank is now going bankrupt on that date? How does one protect themselves against that? So, again, there is this risk of default in financial markets, and that makes them less straight-forward in a way than the traditional markets in which one looks at the gains from trade. How can one measure financial trade?

Standard measure economists use to measure trade overtime is the current-account balance, and the definition of the current account balance is a country's income less its expenditure. There should be an accounting identity because the balance of payments has to balance. So, if companies are spending more than their income they have to be settling that by selling some assets, i.e. by borrowing that effectively (Pisani-Ferry, Sapir, 2010).

The current account balance is also the net amount lent abroad, i.e. the balance of financial flows with the net purchase of the net flows with a net purchase of the foreign assets. So, this 
is one measure of financial trade, i.e. of trade overtime. And if one looks at the data, it is quite striking what happened after, say, the early 1990 s and the mid-1990s, which is the sheer size in dollar terms of current-account imbalances which rose in a way that had not been seen ever before in the post-war years (Reinhart, Rogoff, 2011).

One should break here the developed countries out, i.e. mostly the US deficit. But the developing countries that are oil exporters and developing countries that are not-oil-exporters. So, China is in the latter category. Saudi Arabia is in the former category. And a huge deficit which was opened up for the advanced countries balanced pretty much by surplus for developing countries in general. The US deficit reached about 700 billion dollars or about $6 \%$ of the US GDP. So, this is one measure economists can look at.

Some economists can say that was a big change leading up to the global crisis. But there is even a bigger change out there in the international data on external debts and assets which is not these flows of lending, but the actual growth positions.

So, suppose, there is a country that is running a current-account deficit, and it needs to borrow a dollar from foreigners. One way it can do that is to sell foreigners a one-dollar bond, which commits the country to pay them back a dollar with interest at some point in the future. But there are countless other ways of financing the same flow. For example, one could borrow two dollars and lend them one dollar. Or one could borrow a hundred dollars and lend them 99 dollars. And any of these transactions still has a net borrowing by the country of one dollar.

However, there are large gross transactions that go in the other direction. And if one looks at the data, the level of these gross transactions has been growing and has led to gross asset positions that are very large relative to countries' outputs.

Basically, countries have a substantial amount of foreign assets, i.e. of foreign debts. The difference between those is the net foreign debt, or the net foreign assets, i.e. the rate of change which is related to the current account, but these gross positions indeed are prominent. And one can get some idea from these data about gross positions of high-income and emerging markets as measured as the average of foreign assets and liabilities divided by GDP. And for the high- income countries, one can see these numbers getting very big, and they are undoubtedly growing for the emerging countries, too.

These figures conceal a lot of heterogeneity. If one looks at a country like Switzerland, its foreign assets and liabilities are in the order of 8-9 times GDP. For the US, one is looking at numbers like $1.4,1.3$, which are big, since the US GDP is a significant number. So, there are all these gross positions out there. And when one needs to ask how to explain this, it is hard to think about them in terms of diversification of equity markets, because if that were the case, then the US would basically sell off like three quarters of its stock market to the rest of the world, and buy the global portfolio of equities. And, so, the US would have an external debt or external liability to GDP ratio of 0.75 , and instead, it is twice that high. And if one looks at tiny countries like Switzerland, the Netherlands, the UK when economists say tiny, they mean, they are not really tiny, but they are tiny relative to their external portfolios (Yefremenko, 2007).

The problem is that many of these assets are debt-like instruments which involve counterparty risks, i.e. the risks of default, and it is hard to know what is driving this proliferation of gross positions. Some of these are totally harmless. It so happens, for example, that a lot of mutual funds are located in Ireland for tax reasons. And money comes, and that swells the liabilities of the Irish state, and money goes out as the funds are invested abroad. And that swells the assets. It is not a big deal because it has to do nothing with the Irish economy. But in other cases, there is less of a benignant interpretation, or there is a financial stability risk.

So, there was a massive trade in the late 2000 s where US money mutual funds lent to the European banks who invested in the US sub-prime assets. And this ended up leading for the problems both for the money market funds and for the European banks. If companies put their money in the Cayman Islands and re-lend, and the Cayman Islands Bank re-lends it, that is something socially beneficial, or they are just exploiting a desire for secrecy that business can get in the Cayman Islands. There may be things that are positively not beneficial, such as tax evasion or tax avoidance. 
Think about a Russian oligarch whose money round-trips through Cyprus because investments in Russia from Cyprus can qualify as taxpreferred FDI, has a lot of disrupting going on, and one does not know if that is helpful, or it is harmful, and what are the implications for financial stability? Well, at the national level, economists have adopted three basic approaches to safeguarding financial stability. One is deposit insurance that was already mentioned. Another is a lender of last resort, i.e. the central bank which is allowed to print money can always lend to a bank that is facing a depositor run, which is not justified by any fundamentals, and the doctrine of the last resort has been around for quite a long time, and most central banks play this role. The Fed did it large-scale obviously in the global crisis and the ECB in the Eurozone crisis. And the third sort of prone of this approach is that one needs to regulate, supervise and resolve insolvent banks as a way of ensuring financial stability.

Of course, these three things are very much interconnected. And if there is deposit insurance, and if there is a lender of last resort, financial institutions and depositors may take bigger risks. It is what economists call moral hazard. And so regulation is meant to try to deal with those risks and make sure that moral hazard does not undermine the system and does not create enormous costs for taxpayers.

So, one should keep these three approaches in mind, when one asks about a global context. In the global context, the three approaches become problematic in various ways. The discussions get pretty technical pretty quickly, but to list a few of the issues that arise. One is regulatory arbitrage. If countries have open capital markets, their banks and others can shift activities to lightly regulated venues, and this compounds financial fragility. It undermines what national regulators are trying to do. It is also true these days that banks trade in multiple currencies. So, if there is a French bank, it is likely to have a lot of liabilities in dollars and a lot of assets in dollars. And one might say, that the bank is hedged, but it is actually in a precarious situation, even if it is not explicitly facing currency risk because it is likely to be the case that its dollar liabilities are short-term and its dollar assets are less liquid.
And so, a hypothetical French bank still needs the lender of last resort. But the European Central Bank cannot print those dollars that the French bank might need. So, what happens then? In the open economy, banks can become really big. All one has to do is borrow and lend. And a bank has a big balance sheet. But when banks become very big compared to the size of their national economies, it becomes harder for the government to credibly backstop them in various ways that governments do backstop the banking system.

For example, in Spain, Banco Satander has a balance sheet that is bigger than all of Spain's GDP. Spain is fiscally challenged at the moment. So, what do markets think about Satander's credibility in paying its debts? It is a significant problem in the Eurozone now because, in a supposedly integrated financial market, lenders identify financial institutions by nationality and look to the financial health of the governments who are their protectors, and it leads to segmentation of markets.

Another issue is to resolve or to wind down big complex global banks. One of the biggest problems in the global financial system, not just in the US, is the problem of too big to fail. Banks need to be able to fail. And for them to be able to fail and in an orderly way, one needs a whole body of regulations and procedures and needs to know a lot about them.

But when banks are global and complex, there are a lot of pieces, and what one government does to wind down the bank is going to have implications for foreign countries. So, to resolve these banks` problems, one needs international agreements and cooperation. Too big to fail on the global stage is much worse than it is even domestically. At the global level, the problem of financial instability is quite a big one. And a couple of the examples which were given, hopefully, indicate, it did play a big role certainly if not in the genesis, but certainly in the propagation of the global financial crisis.

\section{Major Lessons to Be Learned from the World Financial Crisis}

What have policymakers been doing and how effective has it been? What are the challenges? If one thinks about financial stability in the global context, then there are obviously two broad categories of measures one can think about. The first measure is that countries can 
take by themselves. And the second is measures that need international cooperation. And either of these approaches is problematic, but for different reasons.

In the first case, if one has to deal with a government that is contemplating unilateral action, one first has to ask about the effectiveness because it may be that other governments are not doing the same thing, and they are just going to undermine what the former does. It is a very similar problem concerning regulating $\mathrm{CO}_{2}$ emissions, for example, at the global level. If the US and Europe have strict regulations on emissions, that concerns them only, but what about the rest of the world that is not doing that? So, it is not very effective. It is similar to financial institutions. Only this time, it is called financial pollution.

And if there are just a couple of financial centres that are taking strong actions, a lot of financial activity will move elsewhere, but it will still affect any country when a crisis comes. In addition to that, when a government takes some action, it may have adverse effects on its neighbours. So, they are going to care about what the former does.

The second approach, which is international cooperation, is that it is really hard to create and police international agreements. There is a wonderful example of progress in this area in the World Trade Organization. But once someone gets to the financial sphere, it becomes much harder to police, enforce and agree on what to do. So, there are things that countries can do emerging countries as well as advanced countries.

First of all, a country should not fix their country's exchange rate. That generally comes to tiers. Very few examples of countries have been successfully able to do this over long periods.

Secondly, a country should try to discourage its financial institutions from denominating debts in foreign currencies, even if their books seem balanced, they may not be so. For example, a bank may borrow dollars and lend the dollars to a domestic corporation, but then if the corporation invests in non-dollars, it may end up going bust at which point it cannot pay the bank, and at which point the bank is stuck with dollar liabilities. So, the country should try to control that.

Thirdly, a country should try for better internal regulation if it can. So does the Dodd-Frank
Act in the US. Developing countries have gone to self-insurance through international reserve holdings. If South Korea, say, has banks that have a lot of dire dollar liabilities, and the central bank cannot print dollars to help its banks when they need them, maybe it is good enough if the country is holding billions of dollars in its reserves because then it can lend them to the banks. So, many emerging markets have taken this route. And perhaps the most controversial proposal is that, if one cannot cooperatively handle things with other countries in a rush to the world, then a government should use capital controls, close off its capital account and other use administrative measures.

So, this is a range of things countries can do by themselves and some of them are less controversial than others, capital control being probably the most contentious.

The other issue that has been incredibly important is the Basel process. There is a book that came out a few years ago by Charles Goodheart on the history of this. It is not for the faint-hearted, but it is the definitive history, and it only goes up until 1997. This process began in 1974, very organically where central bank technicians got together and said if they can talk to each other, maybe they can come up with common rules and exchange information in a way that will make their actions more effective. And the Basel Accord has been a huge success at some level, and it has got some more and more recognition and became more and more official.

The most recent wave of this is called $\boldsymbol{B a}$ sel III, which has a lot of provisions. It is a very complex document. It includes minimal levels of bank capital reserve requirements. It has always been the main point of the Basel process. So, a bank has assets, and it has liabilities. One cannot start a bank without some cushion in case one has a negative shock to its assets. This cushion is the bank's equity capital. It is the amount that the bank can stand to lose before it becomes insolvent.

Basel III tries not only to enhance bank capital in quantity and quality but also to set up what they call counter-cyclical capital buffers. If one ever sees that domestic credit is growing quickly, a country can demand that banks supplement their capital. That is this countercyclical buffer. 
So, Basel III is preceding this way. But it is not without critics, and one of the problems with Basel is that it has a very complicated system of riskwading of assets. Banks are allowed to put aside less capital against assets that they deem are less risky. But the formula to calculate that is incredibly complex. It comes right out of the Basel III rule book from the Bank for International Settlements. And this formula describes the bank capital charge against over-the-counter derivatives.

There is a fierce dispute now going on between the US and the European Union about how to apply this to this formula for derivatives. Whenever things get this complex, one should know that one is going to have very well-paid analysts who are figuring out how to gain the system. And so, this is one of the problems.

Another beneficial innovation which was created after World War Two is the International Monetary Fund (IMF), with nearly universal membership of 188 countries. And it lends to governments that lose financial market access, but it does so with conditions. Two main problems with the IMF are that its resources are quite limited. It has about less than a quarter of the resources that China has in its international reserves, for example. And also, the financial assistance it provides is really slow.

So, for example, the IMF started discussing what to do about Ukraine's finances in the first half of March 2015, and the money just became available, but unfortunately things have deteriorated in Ukraine to such an extent that the IMF is saying that actually if the government loses half the country it will need to rethink how much re-lending them. But this problem illustrates why the IMF is not the ideal tool for fighting crises.

Another important innovation is central banks swap facilities which were institutionalised among six big central banks during the global financial crisis. And under these facilities, if the European Central Bank needs dollars to act as a lender of last resort, it gets them from the Fed. If the Swiss National Bank needs euros to act as a lender of last resort, it may get some from the ECB. So, this is a major innovation. It does not include emerging markets for now, although there are some such as Korea, which could easily qualify as such in the near future. So, there is some progress, but more is needed.

The IMF was supposed to have a major reform that was agreed back in 2009, and it has been totally blocked by the House of Representatives. The world needs more harmonisation of regulation, including higher capital requirements, globally. If one is going to think about capital controls, then it is probably better to have some sort of system of agreements for how they get used, such as the World Trade Organization's safeguards for import controls.

The countries of the world need to work hard on tax evasion and money laundering. That is also a major issue. And some economic researchers push the idea that one needs more data and better funding for research. So, that seems obvious, but not everyone agrees.

How to close down systemically important institutions? It is something that governments are talking about but even in Europe that has been a very controversial issue. And the Europeans just agreed on an EU mechanism for that. That was hard enough. And their experience illustrates why it is hard globally to come up with these sorts of agreements by them.

Ultimately, there are these two approaches, which is whether a country does it itself or has international agreements. And if one values international integration at the economic and financial level, the cooperative approach is going to be much better preserving that than allowing countries to retreat behind their own administrative walls. But economists fear if countries cannot cooperate more, one will get more fragmentation, rather than globalisation.

\section{References}

Afontsev, S.A. (2009). Global'niy krizis i regulirovaniye mirovikh finansov [Global crisis and the regulation of world finance]. Mezhdunarodniye protsessi, 19(7), 17-31.

Anrdonova, N.E. (2012). Teoretiko-metodologicheskiy analiz fundamental'nikh prichin vozniknoveniya krizisov i vozdeistviye na MFA [Theoretical and methodological analysis of the fundamental causes of crises and their impact on the IFA]. Vestnik Leninrgadskogo gosudarstvennogo universiteta im. A. S. Pushkina. Ekonomika, 4(6), 19-28. Arner, D.W., Taylor, M.W. (2009). The Global Financial Crisis and the Financial Stability Board: Hardening the Soft Law of International Financial Regulation. University of New South Wales Law Journal. 32(2), 489. 
Beder, S. (2009). Neoliberalism and the Global Financial Crisis. Social Alternatives, 28(1), 18.

Chen, R., Milesi-Ferretti, G.M., Tressel, T. (2012). Euro Area Debtor Countries: External Imbalances in the Euro Area. IMF Working Paper, 2012, 12(236), 1-22.

Chorev, N., Babb, S. (2009). The Crisis of Neoliberalism and the Future of International Institutions: A Comparison of the IMF and the WTO. Theory and Society. 38(5), 459-484.

Dorrucci, E., McKay, J. (2011). The international monetary system after the financial crisis. European Central Bank Occasional Paper Series, 123, 10.

Elyanov, A. Ya. (2009). Mirovoi ekonomicheskiy krizis i razvivayushchiyesya strany [World economic crisis and emerging economies]. Mirovaya ekonomika i mezhdunarodniye otnosheniya, 10, 24-32.

Griesgraber, J.M. (2009). Reforms for Major New Roles of the International Monetary Fund? The IMF Post-G-20 Summit. Global Governance, 15(2), 179.

Helleiner, E. (2009). Special Forum: Crisis and the Future of Global Financial Governance. Global Governance, $15(1), 1$.

Jordà, Ò., Schularick, M., Taylor, A.M. (2011). Financial crises, credit booms, and external imbalances: 140 years of lessons. IMF Economic Review, 59(2), 340-378.

Kemenyuk, V.A. (2009). Poryadok posle krizisa: kakim yemu byt'? [An order after the crisis: how should it look like?]. Mezhdunarodniye protsessi, 3(7), 1.

Kose, M.A., Prasad, E., Rogoff, K., Wie, S.-J. (2009). Financial globalization: A reappraisal. IMF Staff Papers, 1(56), $8-62$.

Lane, P.R., Milesi-Ferretti, G.M. (2011). External Adjustment and the Global Crisis. IMF Working Paper, 11(197), 3-18.

Pisani-Ferry, J., Sapir, A. (2010). Banking Crisis Management in the EU: An Early Assessment. Economic Policy, 25, 341-373.

Reinhart, C.M., Rogoff, K.S. (2011). From Financial Crash to Debt Crisis. American Economic Review, 101(5), 16761706.

Yefremenko, I.N. (2007). Osnovniye napravleniya transformatsii mirovoi finansovoi arkhitekturi v usloviyakh finansovoi globalizatsii [Main directions of the world financial architecture's transformation in the conditions of financial globalization]. Finasi i kredit, 41(281), 43-51.

Роль финансовой глобализации в распространении мирового финансового кризиса

Михаил Жариков

доктор экономических наук, доцент,

профессор Департамента мировой экономики и мировых финансов,

главный научный сотрудник Института мировой экономики и международных финансов, Финансовый

университет, Москва, Россия

Аннотация. В статье анализируются причины распространения финансовых кризисов в начале XXI в., в том числе глобального финансового кризиса 2008-2010 гг., который являлся наиболее серьезным среди ряда мировых кризисов после Великой депрессии 1929-1933 гг. и влияние которого испытывают некоторые развитые и развивающееся страны. В некоторых из них сохраняется высокая безработица, а ВВП не достигает докризисного уровня. Несмотря на оживление экономик Португалии и Ирландии, долговой кризис в зоне евро, еще не преодолен полностью, существует вероятность возобновления или углубления кризиса евро. Начиная с 2016 г. финансовые проблемы усугубились во многих развивающихся странах, включая страны БРИКС. Развивающиеся страны столкнулись с проблемами утечки капитала и девальвации валют. Анализируя вопросы финансовой глобализации и обеспечения финансовой стабильности, автор сопоставляет результаты своего исследования с выводами и предложениями российских и зарубежных ученых.

Ключевые слова: финансовая глобализация; мировой финансовый кризис; БРИКС; международная валютная система 